\title{
PERAN SUAMI DALAM MENDUKUNG KELANCARAN PENGELUARANASI DENGAN PIJAT OXYTOCIN
}

\author{
Ida Prijatni \\ Poltekkes Kemenkes Malang, Jalan Srikoyo No 106 Jember Jawa Timur \\ Email: ida.prijatni59@gmail.com
}

\begin{abstract}
The purpose of this activity is to give skill to husband to be able to do the oxytocin massage to facilitate the production of breast milk to a mother when breastfeeding. Activity method begins with problem identification, followed by program implementation that is through counseling about breastfeeding concept, exclusive breastfeeding, husband role in supporting fluency of milk and oxytocin massage and demonstration of oxytocin massage. Evaluation of redemonstration of oxytocin massage by husband. The result of this activity is the commitment and breastfeeding group, stating that the success of exclusive breastfeeding depends on the role of the father/husband. If the father is committed to exclusive breastfeeding, the mother will be encouraged to breastfeed until the age of 6 months without any additional food. Successful exclusive breastfeeding will support maximum growth and development of the baby.
\end{abstract}

Keywords: husband role, oxytocin massage

\begin{abstract}
Abstrak: Tujuan kegiatan ini adalah memberikan ketrampilan pada suami agar mampu melakukan pijat oxytocin untuk memperlancar produksi ASI pada ibu saat meneteki. Metode kegiatan diawali dengan identifikasi masalah, dilanjutkan dengan pelaksanaan program yaitu melalui penyuluhan mengenai konsep ASI, ASI Eksklusif, peran suami dalam mendukung kelancaran ASI dan pijat oksitosin dan demonstrasi pijat oksitosin. Evaluasi berupa redemonstrasi pijat oksitosin oleh suami. Hasil dari kegiatan ini adalah adanya komitment dan kelompok peduli ASI, menyatakan bahwa keberhasilan pemberian ASI ekslusif sangat tergantung dari peran ayah/ suami. Bila ayah mempunyai komitmen terhadap pemberian ASI Ekslusif maka ibu akan menjadi semangat untuk memberikan ASI sampai dengan usia bayi 6 bulan tanpa makanan tambahan apapun. Pemberian ASI ekslusif yang berhasil akan mendukung pertumbuhan dan perkembangan bayi yang maksimal.
\end{abstract}

Kata Kunci: peran suami, pijat oksitosin

\section{PENDAHULUAN}

Air susu ibu atau ASI adalah makanan ideal bagi bayi yang menyediakan nutrisi untuk perkembangan bayi sehat dan memberikan antibodi terhadap penyakit yang sering terjadi pada anak. Begitu pentingnya air susu ibu, tetapi masih banyak ibu-ibu dan anggota keluarga yang tidak menyadari manfaat ASI utamanya pemberian ASI secara eksklusif. Pemberian ASI eksklusif adalah pemberian ASI setelah persalinan, diberikan tanpa jadwal dan tidak diberi makanan lain, walaupun hanya air putih sampai bayi berumur 6 bulan.

Angka cakupan ASI eksklusif di Indonesia pada tahun 2013 yaitu sebesar 54,3\% dari target nasional $80 \%$. Cakupan pemberian ASI eksklusif di provinsi Jawa Timur tahun 2013 yaitu sebesar $47,8 \%$ dari target $75 \%$. Kabupaten Jember merupakan salah satu kabupaten di Jawa Timur yang masih memiliki cakupan pemberian ASI eksklusif tahun 2014 yaitu $72,41 \%$ dari target $80 \%$. Berdasarkan data Dinas Kabupaten Jember diketahui bahwa Puskesmas Arjasa memiliki angka cakupan ASI eksklusif yang rendah setiap tahunnya dan menempati urutan lima Puskesmas yang memiliki angka cakupan ASI eksklusif terendah di Kabupaten Jember sejak tahun 2010-2014 yaitu sekitar $30 \%$ dari target $80 \%$, salah satu faktor determinan rendahnya cakupan adalah kurangnya support dari lingkungan seperti suami, orang tua, mertua dan lingkungan masyarakat lainya.

Upaya yang sukses untuk mempromosikan praktik pemberian makan yang baik harus fokus 
tidak hanya pada ibu tetapi pada orang-orang yang mempengaruhi keputusan seorang ibu, seperti ibu, ibu mertua, dan suaminya. Dukungan suami nyatanya tidak hanya bisa membuat proses pemberian ASI menjadi lebih lancar dan berkualitas. Kedekatan istri secara emosi dengan suami yang memberikan dukungan penuh juga akan meningkatkan sisi romantisme pasangan. Ini akan berakibat baik untuk membuat hubungan menjadi lebih harmonis, dan mendatangkan efek yang bagus bagi ibu menyusui. Untuk memperlancar produksi ASI, suami juga dapat membantu merangsang refleks oksitosin yaitu dengan pijat oksitosin. Pijat oksitosin adalah pemijatan pada daerah tulang belakang leher, punggung atau sepanjang tulang belakang (vertebrae) sampai tulang costae kelima sampai keenam. Salah satu hormon yang berperan dalam produksi ASI adalah hormon oksitosin. Saat terjadi stimulasi hormon oksitosin, sel-sel alveoli di kelenjar payudara berkontraksi, dengan adanya kontraksi menyebabkan air susu keluar lalu mengalir dalam saluran kecil payudara sehingga keluarlah tetesan air susu dari puting dan masuk ke mulut bayi.

Tujuan kegiatan pengabdian masyarakat ini adalah memberikan ketrampilan pada suami agar mampu melakukan pijat oxytocin untuk memperlancar produksi ASI pada ibu saat meneteki.

\section{METODE}

Sasaran didalam pengabdian masyarakat ini adalah diutamakan ibu nifas yang sedang meneteki bayinya, namun kondisi sosial budaya yang tidak memungkinkan (karena ibu nifas pada 40 hari setelah kelahiranya dilarang keluar rumah) maka sasaran dialihkan kepada ibu hamil trimester ke III dan suami. Meskipun informasi ini dapat diberikan kepada semua ibu hamil dan suami dalam rangka menyiapkan proses laktasi sedini mungkin dan membangun pola pikir suami sebagai seseorang yang dekat dengan ibu dan mempunyai hubungan emosional yang kuat untuk dapat berperan secara aktif dalam mendukung pemberian ASI. Jumlah sasaran adalah 25 orang.
Metode kegiatan ini antara lain 1) identifikasi masalah, 2) Pelaksanaan program melalui penyuluhan mengenai konsep ASI, ASI Eksklusif, peran suami dalam mendukung kelancaran ASI dan pijat oksitosin. dan demonstrasi pijat oksitosin, dan 3) Evaluasi

Pengabdian masyarakat ini dilakukan di BPM “S “ Kecamatan Patrang Kabupaten Jember, dan dilakukan pada bulan Juni sampai dengan Desember 2016.

\section{HASIL DAN PEMBAHASAN}

Kegiatan pengabdian masyarakat tentang peran suami dalam mendukung kelancaran pengeluaran ASI dengan Pijat Oxytocin di BPM "S" Jember dilaksanakan dengan memberikan penyuluhan dan melakukan demonstrasi bagi suami. Kegiatan dilaksanakan selama 4 (empat) kali. Kegiatan tersebut antara lain:

\section{Pertemuan ke-I}

Pertemuan pertama dilakukan pemberian materi tentang Air Susu Ibu (ASI) yang dihadiri oleh 25 peserta yaitu ibu hamil trimester III. Ratarata ibu yang datang masih memiliki anak satu dan sedang hamil kedua. Dalam pertemuan ini, dilakukan interaksi tanya jawab kepada peserta yaitu apa saja yang diketahui mengenai Air Susu Ibu (ASI).

\section{Pertemuan ke-II}

Diskusi tentang materi ASI eksklusif, dimana diskusi berjalan dengan baik dan peserta aktif dalam memberikan pertanyaan mengenai ASI Eksklusif, yaitu apa manfaat ASI Eksklusif, berbedakah anak yang diberi ASI Eksklusif dengan yang diberi susu formula sejak lahir, bagaimana caranya agar air susu ibu (ASI) tetap banyak selama minimal 6 (enam) bulan, bagaimana penyimpanan ASI yang tepat. Dalam pertemuan kedua ini pula, menentukan jam untuk pertemuan selanjutnya karena suami diharapkan ikut hadirdiberikan materi peran suami dalam mendukung kelancaran pengeluaran ASI. 


\section{Pertemuan ke-III}

Pada pertemuan ini dihadiri 50 peserta, diberikan materi peran suami dalam mendukung kelancaran pengeluaran ASI. Dimana dalam pertemuan ini, peserta sangat antusias karena ratarata masih banyak suami yang belum memberi dukungan lebih terhadap istrinya dalam pemberian ASI. Banyak sekali pertanyaan yang menanyakan bagaimana cara agar suami ikut berperan aktif dalam mendukung istri memberikan ASI terhadap anaknya. Diskusi berjalan dengan kondusif, dimana para suami ikut menanyakan cara dalam berpartisipasi mendukung istri dalam memberikan ASI, dengan diselingi canda tawa dan memberikan masukan terhadap suami terlihat para suami antusias mendengarkan penjelasan yang diberikan.

\section{Pertemuan ke-IV}

Pertemuan ke empat dihadiri 25 orang ibu dan 18 orang suami karena sebagian suami tidak bisa datang karena masih bekerja. Pada saat ini materi yang diberikan adalah mengenai Pijat Oksitosin dimana didalam materi ini dijelaskan pengertian pijat oksitosin, tujuan pijat oksitosin, manfaat pijat oksitosin, persiapan pijat oksitosin dan teknik pemijatan oksitosin. Sebelum dilakukan demontrasi pijat oksitosin dilakukan pemaparan materi terlebih dahulu dan dilanjutkan dengan tanya jawab.

Tanya jawab tentang pijat oksitosin berkisar bagaimana teknik yang benar melakukan pijat oksitosin, dan kapan sebaiknya dilakukan. Semua hal-hal penting yang harus diperhatikan dalam melakukan pijat oksitosin diulang kembali dengan petugas dan ditunjukkan dengan melakukan pemijatan pada panthom secara setahap demi setahap yang disaksikan oleh semua ibu dan suami dengan seksama.

Setelah melakukan pemijatan dengan panthom dilanjutkan pemijatan pada salah satu petugas (antar petugas) sehingga ibu-ibu dan suami dapat melihat dengan jelas bagaimana posisi yang nyaman pada saat dilakukan pemijatan oksitosin. Pemijatan ini memang tidak langsung dilakukan pada ibu hamil karena ditakutkan dengan dilakukan pemijatan langsung pada ibu hamil akan merangsang pengeluaran hormon oksitosin sehingga akan merangsang kontraksi uterus. Posisi nyaman pada ibu ini dijelaskan secara rinci karena ibu pada saat dilakukan pemijatan bra harus dibuka dan buah dada tergantung dengan natural saat ibu dalam posisi menelungkup. Baju semua sebatas pinggang keatas dibuka sehingga saat ini membutuhkan tempat yang sangat privasi sehingga baik ibu dan suami terhindar dari rasa malu.

Setelah itu dilanjutkan dengan demonstrasi antara suami secara bergantian. Disini suami diposisikan menelungkup kemudian dilakukan pemijatan oksitosin oleh suami yang lain sambil diberi pengarahan cara yang benar bagaimana

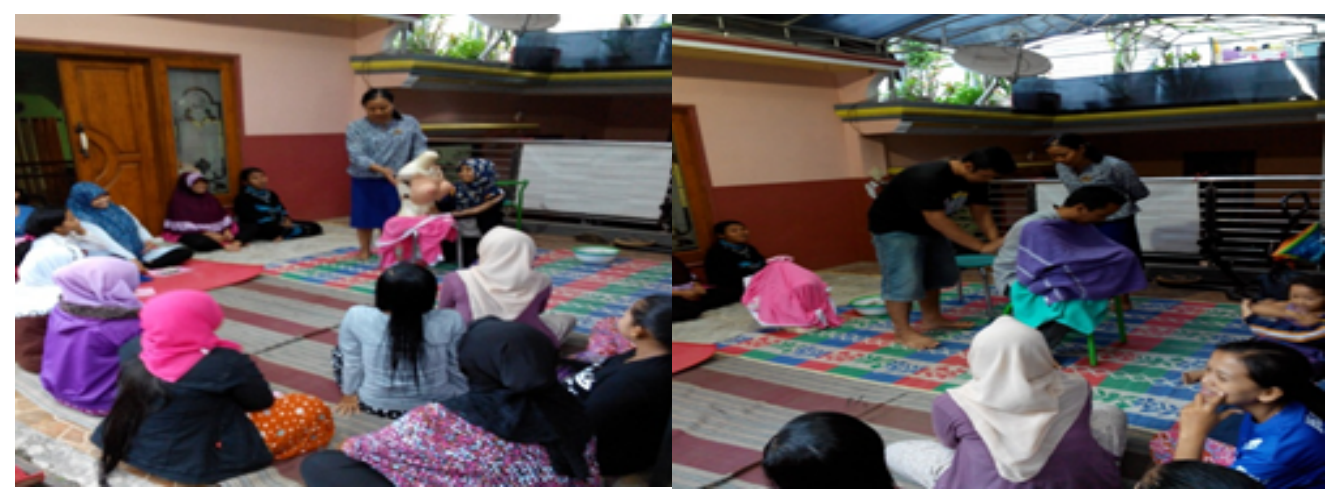

Gambar 1. Demonstrasi dan Redemonstrasi Pijat Oksitosin Kepada Ibu dan Suami 
melakukan pemijatan, terutama kekuatan penekanan pada "cervikal vertebrae ke-7 “. Juga bagaimana cara memberikan sentuhan pada buah dada dan puting susu ibu sehingga ibu merasa nyaman. Pada saat ini suami menjadi lebih antusias dan ingin semuanya mencoba meskipun dengan diselingi dan senda gurau tetapi semua proses dilaksanakan dengan baik dan benar.

Bentuk evaluasi pada suami dilakukan redemonstrasi dengan alat ukur SOP Pijat Oksitosin dari hasil evaluasi praktek pijat oksitosin yang dilakukan oleh suami semua berada dalam nilai yang baik. Hanya ada kekurangan sedikitsedikit hal ini disebabkan para suami belum melakukan pemijatan tersebut dengan hati, sehingga masih tampak kaku dan malu-malu. Tetapi secara keseluruhan hasilnya adalah baik.

Setelah semua sudah dilaksanakan pada akhir pertemuan petugas memberikan pesan-pesan agar ketrampilan para suami terhadap pijat oksitosin betul-betul dilaksanakan pada saat ibu sudah melahirkan dan harus meneteki. Keberhasilan pemberian ASI utamanya ASI eksklusif sangat tergantung dari peran ayah/ suami. Bila ayah mempunyai komitmen terhadap pemberian ASI Ekslusif maka ibu-ibu akan menjadi semangat untuk memberikan ASI nya sampai dengan usia bayi 6 bulan tanpa makanan tambahan apapun. Pemberian ASI ekslusif yang berhasil akan mendukung pertumbuhan dan perkembangan bayi yang maksimal.

\section{PENUTUP}

Pemberian materi peran suami dalam mendukung kelancaran pengeluaran ASI dengan pijat oksitosin berjalan dengan lancar, pertanyaan yang sangat baik dari ibu maupun suami sudah dijawab dan dijelaskan dengan jelas dan dengan bahasa yang mudah dimengerti

Praktek pijat oksitosin oleh suami sudah diikuti dengan baik dan suami sangat antusias sehingga banyak yang ingin mencoba dan mempraktekanya.
Peran serta petugas (Bidan, pembantu bidan) dalam proses pengabmas ini sangat baik, dengan mengikuti semua proses dan melakukan penjemputan bagi ibu hamil yang rumahnya jauh/ tidak ada yang mengantar

ASI ekslusif optimis dapat memenuhi target bila semua suami dilatih melakukan pijat oksitosin dan ditingkatkan pengetahuanya tentang pentingnya ASI ekslusif sehingga secara pasti suami akan mendukung istri dalam memberikan ASI eksklusif.

Adanya kerjasama yang lebih mudah dengan Dinas kesehatan sehingga pengabmas untuk selanjutnya bisa mendapatkan lahan yang lebih luas namun terjangkau.

\section{DAFTAR PUSTAKA}

Depkes, RI. (2007). Profil Kesehatan Indonesia tahun 2006. Departemen Kesehatan Republik Indonesia. Jakarta.

Depkes, RI. (2005). Kebijaksanaan Departemen Kesehatan tentang Peningkatan Pemberian Air Susu Ibu (ASI) Pekerja Wanita. Pusat Kesehatan Kerja, Departemen Kesehatan Republik Indonesia, Jakarta.

Depkes, RI. (1997). Petunjuk Pelaksanaan ASI Eksklusif Bagi Petugas Kesehatan Puskesmas. Direktorat Jendral Binkesmas, Direktorat Bina Gizi Masyarakat Departemen Kesehatan Republik Indonesia, Jakarta.

Maulana, H. (2009). Promosi Kesehatan. Jakarta. EGC.

Notoadmodjo, S. (2002). Pendidikan dan Perilaku Kesehatan. Jakarta. Rineka Cipta.

Prasetyono, Sunar, Dwi. (2009). Cara menyusui yang Baik. Jakarta. Arcan.

Roesli, Utami. (2000). Buku Pintar ASI Eksklusif. Yogyakarta. Diva Press.

Roesli, Utami. (2007). Mengenal ASI Eksklusif. Jakarta. Trubus Agriwidya.

Roesli, Utami. (2008). Inisiasi Menyusui Dini. Jakarta. Trubus Agriwidya.

Soetjiningsih. (1997). ASI Petunjuk untuk Tenaga Kesehatan. Jakarta. EGC.

Sri Purwanti, Hubertin. (2004). Konsep Penerapan ASI Eksklusif. Jakarta. EGC. 